\title{
Os fatores espaciais e materiais da produção e os mercados globais
}

Stephen G. Bunker - Professor do Departamento de Sociologia da University of WisconsinMadison

\section{Resumo}

Muitos autores tentaram incorporar o local ao global. Todavia, compreender a expansão e a intensificação das relações sociais e materiais do capitalismo que criaram e sustentam o crescimento dinâmico do sistema-mundo do local ao global requer a análise de processos materiais da produção natural e social no espaço como diferenciado pela topografia, pela hidrologia, pelo clima, e pela distância absoluta entre lugares. Neste artigo, eu considero algumas das configurações que estruturaram os efeitos locais em formações globais dentro de uma única região, a bacia espacial e material da Amazônia. Deste modo, a Amazônia é mais um dos ambientes específicos que forneceram matérias- primas para dinamizar os mercados globais, mas é preciso considerar como seus atributos materiais e espaciais deram forma a economia global fornecendo introspeç̧ões nas maneiras que outros sistemas locais afetam o sistema- mundo.

\section{Abstract}

Many authors have attempted to incorporate the local into the global.However, understanding the expansion and intensification of the social and material relations of capitalism that have created and sustain the dynamic growth of the world-system from the local to the global requires analysis of material processes of natural and social production in space as differentiated by topography, hydrology, climate, and absolute distance between places. In this article, I consider some of the spatio- material configurations that have structured local effects on global formations within a single region, the Amazon Basin. The Amazon is but one of the specific environments that have supplied raw materials to changing global markets, but close consideration of how its material and spatial attributes shaped the global economy provides insights into the ways other local systems affect the world- system.

\section{Palavras- chave}

Local, global, espaço, processos materiais, Amazônia.

\section{Keywords}

Local, global, space, material processes, Amazon. 


\section{INTRODUÇÃO}

Incorporar o local ao global, de forma analiticamente compatível, é um grande desafio para os estudiosos dos sistemas mundiais e da globalização (CHASE-DUNN; KAWANO; BREWER, 2000; TOMICH, 2000; ROBINSON, 2001). A maioria desses autores tentou fazer essa incorporação, considerando que a análise dos sistemas mundiais baseiase em processos de produção e que toda produção permanece profundamente local. Em vez de buscar o local no global, propomos examinar os modos pelos quais o local - e particularmente aquilo que se manifesta nos fatores espaciomateriais da produção - estrutura e organiza o sistema mundial. Entender a expansão e a intensificação das relações sociais e materiais do capitalismo, que provocou e ainda sustenta o crescimento dinâmico do sistema mundial, requer uma análise dos processos materiais da produção natural e social no espaço. Examinar os efeitos do local e do global requer a consideração do espaço como algo materialmente diferenciado pela topografia, pela hidrologia, pelo clima e pela distância absoluta entre os lugares. Este capítulo sugere alguns passos em direção a esse objetivo, levando em consideração configurações espaciomateriais que estruturaram efeitos locais nas formações globais dentro de uma região topográfica, hidrológica e geologicamente distinta: a Bacia Amazônica.

Primeiramente, examinamos a tendência das análises de sistemas mundiais, da globalização e das ciências sociais modernas, em geral, para utilizar metáforas espaciais para ligar ou contextualizar processos, sem considerar os efeitos do espaço nos processos materiais em torno dos quais os atores sociais organizam a economia e a política. Examinamos, em seguida, o trabalho de alguns cientistas sociais, que analisaram configurações espaciais e materiais específicas que estruturaram atividades e organizações sociais, econômicas e políticas. Foram também examinadas as ferramentas teóricas e metodológicas, fornecidas por esses estudiosos, usadas na elaboração de uma análise que parte do detalhe local para o sistema global.

Em seguida, foram estudadas as mais recentes análises dos efeitos espaciais e materiais na organização social e econômica da Bacia Amazônica, a maior e mais complexa floresta tropical do mundo e histórica e atualmente - uma fonte significativa de matéria- prima crítica para a indústria mundial.

Concluímos com algumas considerações sobre os efeitos espaciais e materiais das interações socioambientais, que impulsionam a expansão da reprodução do capital e são por ela impulsionadas. A produção 
industrial acelerou o consumo de matéria- prima, aumentando, assim, o espaço absoluto através do qual um número e um volume cada vez maiores de materiais são transportados. Demonstramos que a globalização - identificada como um fenômeno recente ou novo por Sklair (2000) e outros - é, de fato, a mais recente fase da expansão e da intensificação espaciais e materiais, causadas pelas inovações tecnológicas. Estados, empresas e setores interagem em uma colaboração técnica, financeira e política para desenvolver e implementar essas tecnologias. Essa colaboração gera incidentes episódicos de crescimento dramático em economias de escala, na produção industrial, na extração de matéria- prima e no transporte.

As economias de escala, organizadas e tecnificadas, impulsionam a reprodução expandida de capital, porém o aumento do espaço absoluto através do qual o crescente volume de matéria consumida precisa ser transportado eleva o custo por unidade. A contradição entre as economias de escala e o custo do espaço cria uma tensão a partir da qual emerge uma nova organização de transporte, com custos reduzidos. Tentamos mostrar que esses processos (1) impulsionam a ampliação espacial dos mercados de matérias- primas e, portanto, (2) estimulam o desenvolvimento de tecnologias progressivamente mais baratas, mais rápidas e de infra- estrutura mais extensiva para o seu transporte, (3) acelerando a globalização da economia mundial. Argumentamos que a globalização pode ser mais bem entendida ao concentrarmos nossa análise na expansão e na intensificação das configurações espaciais e materiais da extração, do transporte e da produção ${ }^{1}$ locais, ao longo dos séculos.

\section{1 - ESPAÇO E NATUREZA NA MODERNA ANÁLISE CIENTÍFICA E SOCIAL}

Os analistas de sistemas mundiais utilizam termos espaciais centro, periferia, mundo, global - como uma metáfora conceitual e organizada de forma central, porém raramente elaboram os mecanismos e processos mais fundamentais que expandem e intensificam as relações sociais e materiais do capitalismo em todo o planeta. É bastante peculiar esse lapso, à luz das enfáticas explicações encontradas nas teorias econômicas marxistas e clássicas sobre os mecanismos que favorecem a aglomeração ou a concentração espacial da produção industrial. A

${ }^{1}$ A té mesmo o transporte, movimento da matéria através do espaço, é, a cada momento, tão local quanto a localização do veículo e do capital empatado no ambiente construído a cada ponto do espaço atravessado. 
primeira razão da dispersão espacial progressiva da produção é o fato de a reprodução expandida do capital criar a necessidade de uma maior variedade de matérias- primas em maiores volumes. As diversas condições topográficas, hidrológicas, geológicas e atmosféricas são necessárias para a produção desses diversos tipos de matérias. 0 espaço torna-se, simultaneamente, um meio e uma condição para a produção e um obstáculo, ou custo, ao transporte. 0 vasto conjunto de matériasprimas consumidas na produção industrial em expansão é, desse modo, disperso entre vários locais ecologicamente diferentes. As economias industriais expandem-se materialmente, ao mesmo tempo que se aglomeram espacialmente. A acelerada exaustão das fontes mais próximas de cada tipo de matéria-prima aumenta a necessidade de encontrar novas fontes ao longo do espaço expandido, criado pelo aumento do consumo. As economias industriais precisam, portanto, encontrar matérias- primas que estão a distâncias cada vez maiores. 0 aumento do custo em relação à distância incentiva os países, empresas e agentes financeiros a desenvolver meios de transporte mais eficientes em tecnologia e infra- estrutura. As sucessivas campanhas e estratégias das nações que competem pela dominação do comércio mundial portugueses, holandeses, ingleses, norte- americanos e japoneses - já ultrapassaram, cada uma a seu turno, a capacidade existente de encontrar e transportar de forma barata, em grandes distâncias, as matérias- primas utilizadas em grande volume. Os efeitos cumulativos desse aumento tecnológico e infra- estrutural têm globalizado, progressivamente, a economia mundial.

Inovações tecnológicas e organizadas socialmente para reduzir os insumos necessários por unidade de produção e para reduzir os custos de transporte ${ }^{2}$ por unidade reiteram (HAYDU, 1998) e ultrapassam (ARRIGHI, 1994) o poder e a escala seqüencial das primeiras soluções encontradas para a contradição entre escala e espaço. Cada solução depende da expansão das economias de escala. Cada aumento na escala acelera a exaustão das fontes mais próximas de matéria-prima e leva a uma busca por novas fontes, a distâncias cada vez maiores. Cada um desses episódios perpetua e exacerba o ciclo de contradições entre economias de escala e custo do espaço.

A contradição entre escala e espaço é constante, porém cada solução está inserida na interseção (1) da organização geográfica, demográfica, política e financeira da nação em expansão econômica e (2) das inovações tecnológicas que impulsionam seu crescimento

${ }^{2}$ Custos unitários de transporte podem ser calculados por tonelada/milha, isto é, peso/distância. 
econômico com (3) as características espaciais e materiais das matériasprimas de que essas novas tecnologias necessitam. As reiteradas soluções para essa contradição somente terão sucesso, a cada instância, se levarem em consideração as propriedades topográficas, espaciais e materiais da produção local.

A escala de contradição aumenta em cada ciclo sistêmico de acumulação (ARRIGHI, 1994). Portanto, cada solução tende a ser dependente de escala (BUNKER; CICCANTELL, 2001). As reiteradas soluções são seqüencialmente cumulativas, ou seja, cada solução individual é distinta quanto às características de sua inovação tecnológica e quanto às fontes de matérias- primas, porém a escala de sua tecnologia e a distância percorrida pelas matérias-primas acumulam-se seqüencialmente. As soluções reiteradas - seqüencialmente cumulativas, porém espacialmente e materialmente distintas para a contradição entre escala e espaço - constituem um mecanismo central por trás da expansão e da intensificação do sistema mundial. Em outras palavras, o local - em toda a sua diversidade natural - conduz, de forma significativa, o global em direção à sua aparente homogeneidade social.

Os analistas do sistema mundial e da globalização esqueceram-se dessa contradição entre escala e espaço, ignorando, assim, suas conseqüências dinâmicas, seguindo, com isso, as tendências mais gerais das ciências sociais. Durante metade do século passado, os cientistas sociais inclinaram-se a considerar o espaço como um contexto passivo, um contêiner, ou um limite da organização e da atividade social. 0 espaço assim concebido não é nem analisado, nem teorizado.

Por isso, os geógrafos modernos, ao tentar analisar ou teorizar o espaço, enfatizaram a sua construção social. Neil Smith (1984), por exemplo, incorpora as noções de Schmidt sobre a segunda natureza nas discussões de Harvey (1983) acerca do ambiente construído, ao declarar que a dinâmica do capital leva a uma reconstrução social da natureza, incluindo o espaço. Assim sendo, ele interpreta a afirmativa de Marx (1967) sobre o tempo que anula o espaço em uma visão generalizada de que o capital recria a natureza e o tempo. A subseqüente crítica de $S$ mith à renovada atenção aos primeiros textos marxistas de Wittfogel (1985) trai a extensão da infeliz batalha dos geógrafos contra os excessos do determinismo ambiental, enquanto a análise geopolítica continua a restringir o foco dos geógrafos radicais às características e aos efeitos naturais do espaço sobre a sociedade. As visões supersocializadas sobre o espaço, de acordo com Lefebvre (1991) e Soja (1989), manifestam uma rejeição igualmente dogmática de qualquer consideração sobre aquilo que Smith chama espaço absoluto, ou natural. 
Mesmo que David Harvey (1983) tenha falado sobre as características materiais do espaço, ao examinar as teorias de Marx sobre arrendamento diferenciado, suas explicações acerca da incorporação de um novo espaço nas expansões econômicas baseiam-se totalmente nas noções de superacumulação e de desvalorização local específica de capital, ignorando, assim, as lições de Marx e de von Thunen sobre matéria e espaço.

\section{2 - CONFIGURAÇÕES ESPACIAIS E MATERIAIS NOS PRIMÓRDIOS DO PENSAMENTO CIENTÍFICO E SOCIAL}

As primeiras tradições científicas sociais levaram muito mais a sério o efeito material do espaço sobre a economia. Wittfogel (1985) não estava sozinho em sua atenção à lógica espacial e material da hidrologia e da topografia. Na primeira metade do século passado, historiadores econômicos descritivos, como Richard Albion (1926) ou Harold Innis (1956) analisaram, simultaneamente, economias extrativas específicas localizadas no espaço, considerando (1) os atributos materiais da topografia, da geologia, da hidrologia e do clima que produziam o recurso extraído e (2) as características topográficas e hidrológicas do espaço entre o local da extração e o local do consumo, pois tais características afetavam a tecnologia e o custo do transporte através das distâncias. Innis e Albion utilizaram a análise espacial e material, que explicava como e por que os esforços de grupos dominantes na Europa estruturaram a conquista, o povoamento e a exploração dos territórios incorporados pelos sistemas imperialistas europeus.

Para Albion (1926), tanto a construção naval como a metalurgia na $\mathrm{Grã}$-Bretanha eram limitadas pela localização, pelo acesso e pelo custo do transporte da madeira ${ }^{3}$. 0 curso dos rios navegáveis e a localização dos solos e climas propícios ao crescimento das diferentes espécies de árvores determinavam a localização e a organização dessas indústrias econômica e politicamente críticas, conforme a crescente demanda de ferro e navios esgotava o estoque doméstico de carvalho para carvão vegetal e madeira. Essas mesmas considerações influenciaram as estratégias imperiais de um estado britânico enormemente sensível às necessidades do Almirantado com relação a embarcações e canhões.

Albion (1926) demonstrou que as características materiais mastros, quilhas, pranchas de porões, leme ou calafetagem e piche -

\footnotetext{
${ }^{3}$ Albion, por exemplo, observou que o custo da tração animal limitava o corte das árvores a uma área de três milhas de distância da margem do rio.
} 
dos diversos tipos de embarcações exigiam forças, flexibilidades, formatos, seivas e tamanhos específicos das várias espécies de árvores que cresciam em climas, solos e elevações também específicos. Albion (1926) utilizou esses detalhes espaciais e materiais para explicar a geografia da expansão imperial e as relações comerciais da $\mathrm{G}$ rãBretanha, bem como a organização das relações trabalhistas, o transporte e a troca em zonas incorporadas à periferia fornecedora de matériaprima à Grã-Bretanha.

De forma semelhante, para Innis (1956), a incorporação do espaço canadense à economia mundial estava atrelada às necessidades materiais da Inglaterra, França e Espanha, em suas lutas pela expansão econômica e pelo poderio militar. Naqueles espaços estruturados segundo a topografia, a hidrologia, a geologia e o clima, os processos naturais, que transformavam matéria e energia em peixes, castores, diferentes espécies de árvores e diferentes metais e combustíveis, juntamente com os modos pelos quais as formas dos sistemas fluviais e terrestres interagiam com as tecnologias de transporte para determinar o custo da exportação dos produtos, moldaram a organização social, econômica, política e demográfica, com conseqüências para a exploração dos recursos naturais no Canadá.

Para Innis (1956), o espaço como condição diferenciada da produção natural, combinado com o espaço como obstáculo à troca ou à exportação, determinou a composição material e a localização das diversas economias extrativas. Ocorrências de características espaciais e materiais naturais interagiam com tecnologias socialmente construídas, mercados e forças geopolíticas, para determinar a organização do trabalho, os modelos de povoamento, as características demográficas das diferentes populações, a composição do capital, a infra- estrutura na qual o capital era investido e a organização e a estrutura da nação canadense. $\mathrm{O}$ curso natural, a direção e o tamanho dos rios navegáveis representaram obstáculos e oportunidades para extrair e exportar matérias- primas para os mercados mundiais. A organização social e a inovação tecnológica criaram e adaptaram vários meios de transporte veículos e infra- estrutura - para servir de intermediários entre o espaço, como obstáculo natural ao acesso e à troca, e os rios, que são uma via de acesso e de transporte baratos.

O espaço e as características topográficas que determinaram o tipo e a abundância da produção material naquele espaço determinaram os parâmetros dos sistemas de transporte. Esses sistemas, por sua vez, determinaram a utilidade dos recursos disponíveis e o custo de sua extração e exportação. Determinaram, assim, não somente a estrutura, 
o custo e a lucratividade de cada economia extrativa de exportação, como também a estrutura nacional, social e política. A obrigação por parte do Estado e da sociedade de pagar por esses sistemas afetaram a organização financeira, econômica e política do Canadá, de forma duradoura.

Tal como Albion, Innis relacionou as características espaciais e materiais do núcleo europeu e da periferia norte- americana aos modelos de povoamento e de exploração das áreas recém-incorporadas. A Inglaterra não possuía acesso ao sal barato que a França tinha e, assim, era obrigada a defender espaços de terra para secar o bacalhau pescado nos Grandes Lagos, enquanto sua rival podia salgar o peixe sem ter de levá- lo para a terra. Posteriormente, essa desvantagem na pesca deu à Inglaterra uma vantagem para movimentar-se através do escudo précambriano, em torno do rio St. Lawrence. Primeiro, os ingleses utilizaram esse rio para ter acesso às zonas árticas, cujas temperaturas frias e a tênue população humana criaram o melhor ambiente para as refinadas peles de boa espessura, tão procuradas por proporcionar um conforto elegante durante os invernos europeus. Rotas comerciais, transporte $\mathrm{e}$ infra- estrutura de estocagem, postos militares e assentamentos populacionais desenvolveram-se para dar apoio ao comércio altamente valorizado e de luxo das peles de castor, principalmente em torno dos pontos de carga e descarga, nos tributários do rio principal. Estes últimos facilitaram o influxo de capital e mão- de- obra para a extração da madeira necessária à expansão da frota de transporte militar e comercial da GrãBretanha.

A vantagem inicial adquirida pela Inglaterra com o controle do rio St. Lawrence significava que a Companhia da Baía de Hudson pagava preços relativamente mais altos pelos castores do que aquilo que os franceses podiam pagar. Quando uma companhia francesa penetrou na Baía de Hudson e estabeleceu aquela rota para a Europa como a mais curta do que a que o St. Lawrence podia proporcionar para o acesso dos navios maiores, os ingleses puderam atrair os agentes franceses para as redes de abastecimento da Companhia, controlando, assim, essa rota mais econômica para os mercados. A viagem mais curta e os navios maiores reduziram significativamente o custo das matérias- primas na Inglaterra. As cumulativas vantagens espaciais e materiais contribuíram para a eventual expulsão dos franceses do Canadá, pelo ingleses. A mudança para a Baía de Hudson favoreceu a economia britânica, levando, porém, a uma significativa estagnação econômica dos centros comerciais estabelecidos ao longo do rio St. Lawrence, até que o Estado nacional - sob pressão dos fazendeiros de trigo que foram inicialmente 
atraídos para a região pelas baixas tarifas, pelas terras acessíveis e pelos salários sazonais oferecidos pelo comércio madeireiro - apoiou a construção dos canais, eclusas e ferrovias para melhorar e complementar os canais naturais do rio.

A análise comparativa de Innis (1956) sobre o castor, a madeira e o trigo demonstrou como as características físicas do recurso natural, a topografia de sua localização e as características de seus usos finais e dos mercados afetavam os padrões de assentamento e de comércio, bem como a organização social, econômica e política. Esses mesmos fatores determinavam a proporção entre valor e volume da matéria-prima exportada e, conseqüentemente, a distribuição dos custos e lucros ao longo dos pontos- chave para seu comércio. As características físicas da matéria-prima determinavam, simultaneamente, a intensidade e a organização do trabalho, suas características demográficas e sua localização, bem como os custos e as necessidades para sua reprodução. Combinados, esses fatores determinavam a razão entre o volume das provisões que entravam e dos produtos que saíam. As peles de castor, por exemplo, enviadas rio abaixo em direção à Europa, ocupavam muito menos espaço nos cargueiros do que os bens e provisões enviados de volta pela mesma Europa. As toras e o trigo revertiam essa proporção entre a carga que entrava e a que saía. Essa proporção entre importações e exportações determinava o custo relativo do frete ou da passagem na viagem de ida e de volta. $O$ espaço para carga em um navio vindo da Europa para provisionar o comércio de pele de castor era muito caro, enquanto a passagem em um navio madeireiro retornando quase vazio ao Canadá era muito mais barata. Os custos relativos afetavam diretamente o custo e, conseqüentemente, a velocidade da imigração, o modelo de assentamento e o custo e a disponibilidade da mão- de- obra. Esses custos, por sua vez, determinavam o custo dos bens importados em relação aos produzidos localmente, bem como as chances de estabelecimento de economias produtivas locais. A localização das cidades refletiu a lógica das localizações de carga e descarga, determinadas pelo volume da matéria, pelo tamanho e pela navegabilidade dos rios, bem como pelos padrões formados pelos rios tributários aojuntar-se para formar hidrovias maiores.

A teoria de Innis (1956) sobre matéria e espaço não prevaleceu; entretanto facilitou e estendeu a análise dos processos sociais e econômicos. Ao integrar mecanismos sociais e naturais, ele foi capaz de dar- se conta de fenômenos de conseqüência espacial e temporal, como a demanda mutável e o tamanho da economia mundial, as dimensões políticas e econômicas da resistência imperial e colonial, ou o papel dos 
conflitos entre as potências centrais, primeiro entre a Inglaterra, a França e a Espanha e, mais tarde, entre os Estados Unidos e a Europa. A incorporação de dados espaciais e materiais enriqueceu a análise de Innis (1956) sobre a trajetória econômica, financeira e política da nação e do Estado canadense.

Mesmo os mais meticulosos entre os recentes estudos sobre os efeitos materiais e econômicos do espaço ressentem-se da falta dessa análise mais detalhada sobre mercadorias específicas em determinados lugares. A discussão de Mandel (1975) sobre o modo como as inovações tecnológicas no transporte reduziram as barreiras tarifárias naturais do espaço demonstra sensibilidade a alguns dos atributos físicos do espaço. Douglas North (1958) e mais tarde O'Rourke e Williamson (1999), em suas considerações específicas sobre mudanças técnicas no transporte e seus efeitos no comércio mundial, devotam alguma atenção ao espaço como local naturalmente autônomo da tecnologia e da infra- estrutura produzidas socialmente. Esses trabalhos, entretanto, não logram explicar as interações entre o espaço como condição de produção e, portanto, determinante dos tipos de atividade econômica aptas à exploração lucrativa, e o espaço como obstáculo à troca e, portanto, determinante da localização da atividade humana, materialmente delimitada. Esses estudos não podem, no entanto, atingir a dialética dinâmica, que caracterizava os trabalhos de Innis ou Albion, e que Wittfogel encontrou na análise de Marx sobre os valores de uso naturalmente produzidos. Fornecem, porém, caminhos que podem contribuir para análises que integrem dinâmicas localmente observáveis às relações sistêmicas mundiais.

Estudos sobre economias extrativas na Bacia Amazônica fornecem caminhos similares. Seus autores comparam as limitações espaciais e materiais na economia e na sociedade, que são por demais óbvias para serem ignoradas. Barbara Weinstein (1983), por exemplo, em seu estudo sobre a economia da borracha, observou que a Bacia Amazônica, como objeto de análise, é espacialmente tão grande e topográfica e biologicamente tão complexa que esmaga a moderna tendência de ignorar ou negar os efeitos do espaço natural sobre a observação humana social e econômica. Barbara Weinstein não analisa, explicitamente, os efeitos do espaço e da topografia sobre a organização do comércio da borracha, porém os dados por ela apresentados como base empírica para suas explicações sobre a ascensão e a queda da prosperidade amazônica permitem uma visualização bastante detalhada desses efeitos e um julgamento de sua importância. 
A análise anterior e mais detalhada de RobertoSantos (1968, 1980) sobre as atividades das firmas de comércio local da borracha e as relações financeiras, sociais e comerciais entre elas, com sua mão- de- obra própria, com o Estado e com os compradores e fornecedores internacionais que se localizavam em Belém e Manaus, são uma fonte ainda mais rica de detalhes empíricos. Santos considera o espaço como o local biológica e hidrologicamente determinante e condicionante da produção natural e como determinante topográfico e hidrológico da localização e das relações da produção social e da troca.

Nesse e em outros trabalhos sobre a Amazônia, fica bastante claro que o rio moldou as atividades humanas muito antes e em um grau muito maior do que as atividades humanas jamais modificaram o rio. As descrições de Santos (1968, 1980) e de Weinstein (1983), juntamente com a análise ecológica de Nimuendaju (1954), Palmatary (1960), Lathrap (1977), Sioli (1975) e Fittkau (1973) sobre o Amazonas e seus afluentes, fornecem os dados e as ferramentas conceituais para a construção de um modelo para a interação do espaço, da topografia, da biologia e da demografia do rio e de sua resposta e influência no crescimento industrial, na inovação tecnológica, no comércio internacional e na geopolítica do sistema mundial.

Em Subdesenvolvendo a Amazônia (BUNKER, 1985), elaboramos uma série seqüencial e cumulativa de ciclos extrativos e socialmente organizados, interativamente modelados por (1) transformações tecnológicas, geopolíticas e mercadológicas dentro do sistema mundial e (2) pelas conseqüências demográficas, ecológicas, políticas e econômicas dos esforços sociais locais para obter vantagem sobre as oportunidades, criadas por essas mudanças, no sistema mundial. Em cada um desses ciclos, configurações locais, espaciais e materiais limitaram tanto as ações locais como as do sistema mundial. Nossa estratégia foi ampliar os mecanismos dos estágios de diversificação autocatalítica e de crescimento, subsistentes nos modelos de sucessão ecológica, para incluir efeitos sociais e ecológicos, seqüencialmente cumulativos, de cada ciclo extrativo sobre os recursos sociais e naturais encontrados nos ciclos subseqüentes ${ }^{4}$.

Nas seções seguintes, estão os detalhes sobre o modo como os atores locais e internacionais desses sucessivos ciclos extrativos responderam e mediaram, de um lado, as mudanças tecnológicas e os

${ }^{4}$ A expressão "seqüencial cumulativa" surgiu da leitura das demonstrações de Arrighi (1994) de que cada ciclo sistemático de acumulação incorpora e ultrapassa a expansão atingida pelo ciclo anterior, ao qual ele sucede. Essa idéia é incrivelmente similar às formulações clássicas da sucessão ecológica. 
mercados do capitalismo no mundo e, de outro, as características locais espaciais e materiais, que formaram a substância de sua participação na economia mundial.

\section{3 - 0 ESPAÇO NA GEOPOLÍTICA DA COLONIZAÇÃO E NA SUBORDINAÇÃO E DESTRUIÇÃO DAS POPULAÇÕES INDÍGENAS}

Inicialmente, os portugueses povoaram e fortificaram a Amazônia porque essa região proporcionava um espaço hidrologicamente definido, à disposição das frotas holandesas, para que penetrassem nas plantações de açúcar do Nordeste, ou das frotas portuguesas, para proteger aquele espaço comercialmente lucrativo. A fim de baratear a administração e a defesa da Amazônia, a Coroa portuguesa cedeu a seus oficiais largas concessões de terra e de direito à utilização do trabalho indígena.

0 espaço amazônico não era apropriado - biológica, hidrológica ou climatologicamente - às tecnologias ou às relações de trabalho preferidas pelos portugueses. A exploração econômica portuguesa da Amazônia jamais foi suficientemente lucrativa para comprar ou sustentar mão- de- obra importada. Ao invés disso, os portugueses escravizavam a população indígena e a utilizavam para investimentos maciços e não produtivos na construção de prédios e estradas, bem como na extração de produtos da floresta e dos rios. 0 custo da extração cresceu e os lucros caíram à medida que as expedições exauriam as fontes mais próximas de mão-de- obra e material.

As condições de trabalho e de vida em um povoamento empobrecido, combinadas com a exposição aos germes trazidos pelos navios vindos da Europa, causavam inúmeras epidemias e a conseqüente redução das populações nativas. A necessidade de repor essa valiosa mãode- obra cativa levou os portugueses a empreender um maior número de missões e a provocar mais guerras com fins escravocratas. As missões empurravam as populações indígenas mais e mais rio acima, aumentando a distância necessária às jornadas seguintes e, conseqüentemente, aumentando a necessidade de provisões para os remadores indígenas nos dois trechos da jornada e para os escravos trazidos na viagem de volta. Tanto os remadores como os cativos sofriam de desnutrição, de doenças e muitas vezes morriam, na tentativa de economizar no transporte através desse espaço cada vez maior (HEMMING, 1978; SWEET, 1974).

A maior densidade de população indígena havia se concentrado, antes da conquista, nos lagos dos afluentes do Amazonas, onde as águas calmas permitiam o acesso à proteína dos peixes e tartarugas e as 
enchentes periódicas mantinham o solo fértil. Os lagos e várzeas espaços com solos abundantes e férteis para o cultivo e bastante água para a pesca - tornaram-se também espaços perigosamente acessíveis aos barcos escravocratas dos portugueses. Estes últimos fizeram com que as populações que conseguiram sobreviver às guerras, à doença $\mathrm{e}$ à escravidão fugissem rio acima pelos afluentes do Amazonas para as terras menos férteis e águas menos ricas da terra firme. Escravização, doenças, guerras, fugas e adaptação a terras menos férteis resultaram em uma drástica redução das populações indígenas.

Os atributos naturais do espaço e da matéria dentro dele haviam facilitado e aumentado certas atividades humanas, tais como a caça, a pesca, o cultivo e o transporte, enquanto restringiam outras atividades, incluindo os estilos europeus de agricultura. Esses mesmos atributos de espaço estruturaram as violentas lutas dos portugueses e a reação e a fuga dos indígenas. A interação entre essas duas forças naturais e sociais criou um vácuo demográfico, que impediu seriamente a resposta local quando as mudanças tecnológicas e industriais na Europa e na América do Norte criaram a demanda acelerada de borracha amazônica.

\section{4 - COMO 0 ESPAÇO, 0 TEMPO E A MATÉRIA ESTRUTURARAM AS RELAÇÕES DE PROPRIEDADE, MÃO-DE-OBRA E TROCA NA ECONOMIA DA BORRACHA}

A demanda voraz por borracha começou no início da segunda revolução industrial. Os inventores, engenheiros e capitalistas europeus encontraram um meio de combinar o ferro, o carvão e o vapor para fornecer matéria e energia às máquinas que executavam um número cada vez maior de tarefas. Essas máquinas eram capazes de movimentar cargas muito maiores e com maior rapidez, ao aplicar maior força, a temperaturas bem mais altas, do que qualquer esforço humano ou animal jamais pôde atingir. A inovação e o capital estenderam rapidamente essas funções, ao desenvolver máquinas que transformavam o ferro em novas máquinas.

As empresas pioneiras nessas inovações expandiram seus lucros enormemente; as economias nacionais, onde operavam, atingiram um rápido crescimento econômico, e os Estados que regiam essas economias nacionais aumentaram bastante suas receitas e seu poder. $\mathrm{O}$ controle sobre as matérias- primas, que faziam parte das máquinas e lhes davam força, e sobre as inovações que estenderam seu uso produtivo tinham uma importância crítica para os Estados e companhias. Muitas dessas inovações estimularam a descoberta e o uso de novos tipos de matéria- 
prima; outras adaptaram as máquinas às propriedades físicas e químicas dos novos tipos de material descobertos ou processados.

A tríade ferro, carvão e vapor acelerou, por um lado, a interação histórica entre a tecnologia e o capital e, por outro, a interação entre matéria e espaço. Um dos mais rápidos e dramáticos episódios dessa interação ocorreu quando os engenheiros procuraram adaptar as máquinas às diferentes propriedades físico- químicas dos diversos depósitos de ferro e carvão e os Estados e companhias começaram a procurar novas fontes de material. Essas novas fontes tinham de (1) ser grandes o suficiente para sustentar a escala crescente das novas tecnologias e (2) ter composições físico-químicas que melhorassem a performance das máquinas e a qualidade dos bens produzidos.

Inovações e melhorias nas máquinas e a expansão dos tipos de tarefas que podiam ser mecanizadas foram aumentando a necessidade de transmissão de energia motora entre diferentes planos. As técnicas metalúrgicas ainda não eram tão exatas, nem as ferramentas eram precisas e padronizadas o suficiente para atingir essa transmissão por meio de sistemas de produção em massa de engrenagens, rodas e eixos de aço. Correias flexíveis e fortes o suficiente para manter sua forma e textura ao ser submetidas à fricção e ao calor eram mais práticas e mais baratas. Tecidos e corda tendiam a escorregar ao encontrar resistência, além de se desgastaram muito rapidamente. A borracha proporcionava maior força e aderência, porém tendia a esticar.

A crescente importância das bombas e dos motores movidos a vapor para os lucros empresariais e as receitas estatais, originados em um mundo cada vez mais mecanizado e capitalista, estimulou a busca de tecnologias que pudessem estabilizar a borracha, mesmo sob altas temperaturas e grande fricção. A invenção da vulcanização, por Goodyear, atingiu esse objetivo, em 1939. A borracha assim tratada servia para a transmissão de energia mecânica com correias flexíveis e também para os pneus, que permitiam a mobilidade das máquinas. Subseqüentes pesquisas e investimentos melhoraram ainda mais a vulcanização. Essas melhorias ampliaram, progressivamente, as lucrativas aplicações mecânicas da borracha. Ao mesmo tempo, as inovações tecnológicas, particularmente a invenção da bicicleta e do automóvel, seguidas da rápida mecanização das forças armadas, pressionaram ainda mais a grande demanda por borracha.

Eventualmente, a rápida expansão dos usos mecânicos do aço e o rápido desenvolvimento de novas tecnologias mecânicas incentivaram a invenção, a fabricação e a padronização de ferramentas para maquinário, tais como parafusos, engrenagens, rodas e eixos. À medida 
que os insumos foram tornando-se disponíveis, o aço com o qual eram feitos transmitia mais força, resistia a maiores temperaturas e durava mais do que a borracha. Entretanto, no início da era das máquinas, as qualidades materiais da borracha - natural e socialmente melhoradas permitiam uma execução dessas funções altamente lucrativas, sem necessidade de muita técnica.

A borracha com a qualidade encontrada somente na Amazônia funcionava melhor com essas novas tecnologias. Muitas das mais lucrativas pesquisas e o desenvolvimento de novas tecnologias foram, desse modo, baseados na borracha amazônica. $\mathrm{O}$ paulatino refinamento dessa tecnologia, combinado com a invenção de novas aplicações mecânicas, elevou a demanda da borracha a um patamar muito mais alto do que os sistemas locais de transporte e mão-de-obra podiam proporcionar. Os preços subiram, e as tentativas locais de responder a essa demanda em expansão modificaram radicalmente a economia, a demografia, a política e a lei na Amazônia. As características espaciais e materiais da região e as históricas respostas sociais e econômicas da Europa a essas características impossibilitaram uma resposta satisfatória a essa demanda. As tentativas locais de domar ou manipular o mercado tornaram o fornecimento inadequado e erraticamente volátil.

O boom da borracha coincidiu com um dos mais dinâmicos episódios de intensificação material e de ampliação espacial da economia mundial. A descoberta da vulcanização e a rápida proliferação de novos usos mecânicos para a borracha ocorreram quase paralelamente ao desenvolvimento e à difusão da conversão de Bessemer para a fundição do ferro, tornando o aço mais durável e de qualidade uniforme, a um preço acessível para a produção em massa. A introdução do aço Bessemer é creditada à rápida ascendência da economia norte-americana na segunda metade do século XIX. Os EUA lideraram o mundo com sua velocidade na adoção dos conversores Bessemer e, rapidamente, atingiram a primazia mundial tanto na produção de aço, como na extensão das ferrovias. Por volta de 1890, aquele país ultrapassava as tradicionais indústrias de aço britânicas e alemãs, apesar da expansão ainda acelerada da produção européia.

As novas tecnologias baseadas no aço, que dependiam da borracha, proporcionaram um enorme superávit e estimularam um grande crescimento econômico das potências centrais, que se industrializavam rapidamente, principalmente a Grã-Bretanha e os Estados Unidos. Estabelecimentos industriais e estados nacionais, naqueles países, estavam bastante interessados no fornecimento e no preço da borracha, porém tinham de adaptar-se às estruturas espaciais e materiais, econômicas e políticas da Amazônia para satisfazer suas necessidades. 
Os atores locais que se organizaram para lucrar com a nova demanda de borracha eram diretamente limitados (1) pelas características biológicas da seringueira, Hevea brasiliensis especialmente porque essas características determinavam a distribuição espacial da árvore e a distribuição temporal do processo de mão- deobra envolvido no corte, na coleta e na cura da borracha -, (2) pelos cursos e correntes dos rios, que proporcionavam os únicos meios comerciais viáveis de acesso aos seringais, e (3) pela ocorrência sazonal das chuvas e cheias.

A biologia das árvores e sua distribuição no espaço haviam evoluído em uma larga dispersão espacial de seringueiras, grande o suficiente para impedir a proliferação do dothidella ulei, um fungo que cresce na presença de matas fechadas. A seiva da seringueira pinga tão lentamente que somente uma pequena tigela podia ser colhida a cada dois dias. Portanto, a exploração da borracha exigia que cada trabalhador percorresse grandes distâncias entre as árvores para colher uma quantidade relativamente pequena de borracha por dia. Era preciso então curar a borracha e aglomerá-la a partir de pequenos acréscimos diários até formar uma grande bola ou rolo para trocá-lo pelas dívidas contraídas com os capitalistas, que haviam fornecido o transporte e suprimentos.

Conforme descrito por Albion (1926), assim como o alto custo e a baixa velocidade da tração animal, no século XVII, haviam limitado a extração madeireira às árvores que ficavam a três milhas ou menos de distância das margens dos rios, o tempo e o esforço de carregar o látex através da mata limitava as veredas à distância que um homem podia percorrer para colher e carregar até a margem do rio a produção de um dia de trabalho. $\mathrm{O}$ transporte de mão- de- obra e provisões para o interior, no início da estação seca, e o transporte de mão- de-obra e borracha para fora, no início da estação chuvosa, dependiam completamente dos cursos e correntes dos rios; portanto, os rios determinavam os seringais que podiam ser trabalhados de forma lucrativa. A baixa densidade de seringueiras e a restrição do corte às árvores dentro do circuito de ida e volta para o rio significavam que a resposta à crescente demanda exigia viagens mais longas, rio acima. Isso aumentava a necessidade de mãode- obra e de transporte, elevando os custos e o preço da borracha.

A ausência de população humana nesse espaço resultou, inicialmente, na exploração de escravos, impondo a necessidade de transportar a mão- de- obra e, posteriormente, controlar e disciplinar essa mão-de- obra através do espaço. A baixa densidade de árvores, o lento pingar do látex e a longa e cansativa tarefa diária de aglomerar o látex em uma carga sólida faziam com que o trabalho fosse distribuído durante 
longos períodos de tempo. Capital suficiente teria de ser adiantado para manter os trabalhadores transportados durante um tempo relativamente longo, para acomodar-se aos ritmos lentos e biologicamente determinados do escorrimento do látex e ao lento processo de cura pela defumação e aglomeração, determinado materialmente. 0 controle e a supervisão desse processo de trabalho, bastante disperso e lento, teriam um custo excessivamente alto. 0 controle direto da mão- de- obra, do capital adiantado pelo transporte e pelas provisões e a segurança física da produção eram impossíveis em tais condições.

O espaço, o tempo e a matéria ameaçavam a capacidade capitalista de assegurar o retorno pela apropriação da borracha e a obtenção de lucro para seu investimento. Assim, o capital foi impelido a organizar o processo trabalhista por meio de mecanismos que garantiriam o retorno do investimento em transporte, manutenção e disciplina de trabalhadores isolados, a uma grande distância, durante longos períodos de tempo. Uma solução seria impedir que barcos de propriedade de outros comerciantes transportassem a mão- de-obra ou produtos aos seringueiros, oferecendo-lhes a oportunidade de vender a borracha coletada e fugir para evitar o pagamento do débito contraído pelo transporte e pelas provisões. Outra seria usar de violência exemplar contra qualquer seringueiro que tivesse a infelicidade de ser capturado.

Os comerciantes de borracha ou "seringalistas" criaram costumes e o Estado concebeu formas legais de propriedade e usufruto baseados na corrente dos rios, de forma que o proprietário ou arrendatário de um seringal pudesse também tornar-se o único e legítimo dono dos direitos de transporte em cada rio. Tais direitos podiam ser exigidos pela violência. Nesse sentido, a configuração natural material e espacial da árvore da borracha criou os parâmetros dentro dos quais as relações sociais, econômicas e políticas de propriedade, extração, transporte, troca e sistemas legislativos podiam ser manipulados para adequar-se à situação ecológica e social local e à demanda econômica global ${ }^{5}$.

As mesmas configurações espaciais e materiais que restringiam e modelavam a organização social e econômica do comércio da borracha também limitavam e desestabilizavam o fornecimento a um mundo industrializado, crescentemente dependente da borracha e enriquecido por seu papel na produção. 0 potencial de lucro em tecnologias

\footnotetext{
${ }^{5} \mathrm{O}$ sistema, como um todo, tomou o nome de aviamento. Os comerciantes capitalistas dentro desse sistema eram conhecidos como aviadores. A borracha era produzida em seringais arrendados em aforamentos de longo prazo a seringalistas. Os seringueiros entregavam a borracha que haviam colhido e curado a fim de pagar seus débitos de transporte e mantimentos. 0 seringalista ou aviador, que poderia ou não ser a mesma pessoa, determinava os preços dos mantimentos e do transporte, bem como da borracha entregue em troca. Assim, os débitos dos seringueiros costumavam perpetuar-se de uma temporada para a outra.
} 
dependentes da borracha aumentou ainda mais quando as bicicletas e, posteriormente, os automóveis entraram para o mercado de consumo, como exemplos pioneiros de máquinas feitas para consumo final, em vez de serem limitadas a servir de insumo a outras produções. As naturais limitações de fornecimento aceleraram os esforços científicos para melhorar a vulcanização, de forma a expandir a utilidade da borracha de menor qualidade, bem como os esforços da Grã-Bretanha e da administração colonial para transformar o cultivo da borracha de um recurso silvestre em uma cultura domesticada. Tais esforços, eventualmente, transformaram a borracha de uma planta original da floresta, onde o capital britânico "não controlava nem a terra nem a mão- de- obra”, em plantações na Ásia, onde o capital britânico controlava ambos (BROCKWAY, 1979).

A enxurrada de borracha cultivada nos mercados mundiais, em 1910, reduziu o preço da borracha abaixo dos custos impostos pela esparsa distribuição de seringueiras e pelos altos custos de transporte necessários para extraí-la e exportá- la. Os portos e barcos do sistema de aviamento eram muito caros para serem mantidos nesse novo regime de preços e foram assim se deteriorando, enquanto seu valor remanescente de uso era aplicado em um comércio bastante reduzido de borracha, praticado agora por camponeses autônomos, como uma suplementação a atividades de subsistência mais diversificadas.

Espaço e matéria definiram, desse modo, o modelo pelo qual a Amazônia foi reincorporada ao sistema mundial como fonte de matériaprima crítica e, ao mesmo tempo, criaram as condições que eventualmente levaram a coalizões entre os agentes dos países centrais a fim de procurar novas tecnologias e meios organizacionais para aumentar e estabilizar o fornecimento e reduzir o custo da borracha. Os agentes das empresas industriais e dos Estados imperialistas colaboraram entre si para mudar sua reprodução material e importar populações coloniais para seu cultivo nos novos locais. Tais iniciativas acabaram por empobrecer a economia da Amazônia tão rápida e radicalmente quanto as respostas locais à crescente demanda das nações centrais haviam- na, anteriormente, enriquecido.

A borracha não era o único insumo das tecnologias rapidamente desenvolvidas, com base no ferro, carvão e vapor, que haviam expandido as economias de escala industrial de produção e a velocidade de crescimento e de lucro nas nações industriais. 0 processo Bessemer dependia de minérios e combustíveis com baixo teor de enxofre e de manganês para combinar força com durabilidade. A rápida expansão do processamento do aço exigia a mecanização da mineração e do 
carregamento para o transporte. Novas tecnologias foram desenvolvidas para a mineração e o carregamento, porém, no início, elas exigiam grandes depósitos superficiais de minério soft. Tais características suavidade, minério com baixo teor de enxofre em grandes depósitos de superfície - foram descobertas nos depósitos de minério de ferro na Cadeia do Mesabi, na região Norte dos Grandes Lagos. Naquele local, a complexa interdependência entre características de recursos naturais, topografia, hidrografia, tecnologia, economias de escala e maciça acumulação de capital proporcionaram um desenvolvimento sustentado na área dos Lagos, mesmo quando as regiões fornecedoras de minério sofreram um relativo colapso econômico à medida que os recursos escassearam e as tecnologias modificaram-se. Os depósitos do Mesabi, na época os maiores jamais explorados, eram suficientemente grandes e concentrados para permitir que a ciência, a tecnologia e o capital descobrissem e implementassem novas economias de escala e velocidade. Essas propriedades espaciais e materiais do ferro permitiram que os proprietários das minas, dos navios, das docas e das ferrovias se acomodassem à rápida expansão da demanda. Por volta da década de 50, a intensiva exploração dos minérios de melhor qualidade havia reduzido os depósitos do Mesabi à "taconita" ${ }^{6}$. Esse minério é muito mais duro e de custo mais alto para a mineração e o beneficiamento do que os metais mais suaves e mais favoráveis às primeiras tecnologias de pás a vapor, tirantes e carregadores pesados. Os grandes aumentos observados na força extensora do aço, na precisão dos trabalhos em metal e ferramentas, na força dos motores e na eficiência dos mecanismos para a conversão de calor em energia mecânica e em reações químicas controladas proporcionaram o acesso do capital às novas tecnologias de mineração e transporte. As economias de escala - especialmente quanto à capacidade de carga dos navios e quanto à força, ao peso e à eficiência no consumo de combustível dos motores de combustão interna apoiadas por essas novas tecnologias tornaram possível a exploração dos depósitos na Austrália, América do Sul e África. Por volta de 1973, o minério de ferro e o carvão podiam viajar as milhares de milhas que separavam suas fontes do Japão de forma mais barata do que a U.S. Steel podia movimentar o minério de suas minas ao norte dos Grandes Lagos até suas usinas ao sul. Sistemas ferroviários mais robustos e motores a diesel mais eficientes tornaram economicamente viável transportar enormes carregamentos de ferro e carvão extraídos de minas muito mais distantes de vias navegáveis do que os depósitos do Mesabi.

\footnotetext{
${ }^{6}$ Nota do tradutor: taconita ou taconite é uma variedade de sílex.
} 
Essas novas tecnologias, combinadas com a contínua descoberta de depósitos maiores de minérios de melhor qualidade, em locais tão distantes dos grandes centros industriais que as primeiras tecnologias de transporte acharam por bem deixar de fora da esfera da exploração competitiva, eliminaram qualquer impulso do capital com o objetivo de apoiar pesquisas técnicas de materiais substitutos, ou meios alternativos de encontrar ferro. Essas mesmas tecnologias e descobertas interagiram com os modos como a geologia e a química haviam distribuído os depósitos de minério e carvão ao redor do globo, para criar um forte impulso de baratear o transporte de carga através de espaços mais longos. A U.S. Steel sofreu a desvalorização do capital que havia investido na infra- estrutura e na tecnologia apropriadas à composição química dos minérios do Mesabi e ao tamanho dos navios que podiam navegar entre e dentro dos $G$ randes Lagos. As indústrias do aço no Japão, Europa e Coréia, entretanto, exploraram o transporte mais barato de material a longa distância, aumentando tanto a intensidade material, como a ampliação espacial da produção siderúrgica.

Em comparação, a dispersão das seringueiras e os lentos ritmos biológicos da circulação interna de látex provocaram tamanha limitação à capacidade dos seringueiros e comerciantes de expandir o fornecimento que as empresas e os Estados consumidores entraram em colaboração para alterar as características espaciais - e conseqüentemente as sociais e políticas - da produção da borracha. Estados e empresas foram, posteriormente, compelidos a modificar também as características materiais da borracha. Os EUA e a Alemanha somaram esforços para contornar os impedimentos ao acesso às plantações asiáticas, provocados pelas guerras, e aceleraram as pesquisas de técnicas para fabricar borracha sinteticamente, a partir do petróleo. 0 sucesso conseguido provocou a expansão do fornecimento e a redução do preço da matériaprima essencial ao barateamento e à expansão do tráfego de automóveis, caminhões e aviões, após a Segunda Guerra Mundial. Isto também causou uma queda ainda maior no preço da borracha.

\section{5 - TOPOGRAFIA E HIDROLOGIA NA EXTRAÇÃO DE PLANTAS E ANIMAIS}

Os múltiplos estudos sobre a extração da flora e da fauna na Amazônia fornecem perspectivas complementares sobre os modos como a matéria e o espaço primeiro moldam as respostas locais à demanda de novos recursos do sistema mundial para depois estruturar as 
conseqüências ecológicas e sociais dessas respostas. Os dados apresentados por Alden (1976) e por Sweet (1974) sobre a extração do cacau, por Nigel Smith (1974, 1980-1981) sobre a captura de tartarugas, peixes-boi e jacarés, com o conseqüente empobrecimento da captura de energia biológica e de troca no rio e na várzea, e a análise de Fittkau (1973) sobre as funções espaciais e materiais do jacaré na manutenção da fertilidade necessária aos peixes nos lagos dos afluentes indicam a autonomia dos sistemas naturais, espaciais e materiais da Amazônia e a extensão da adaptação desses sistemas às formas bem-sucedidas de extração, feitas pelos seres humanos. As atividades humanas podem produzir profundas, complexas e imprevisíveis conseqüências em tais sistemas, mas essas mesmas conseqüências ocorrem por meio de interações dinâmicas naturais de processos espaciais e materiais, embora muitas intervenções humanas possam ter sido as catalisadoras dessas mudanças.

\section{6 - IMPLICAÇÕES DOS CICLOS DE EXPORTAÇÃO NA AMAZÔNIA NA ANÁLISE ESPACIAL E MATERIAL}

As iniciativas humanas para explorar os recursos produzidos em localidades específicas podem ter sucesso somente se estiverem adaptadas às características espaciais e materiais dessas localidades. Em todos os ciclos extrativos da Amazônia - as guerras escravocratas, o comércio de tartaruga, peixe, jacaré, peixe-boi e capivara, o boom da borracha e seu posterior declínio -, o sistema fluvial, como um espaço hidrológica, topográfica, biológica e materialmente diferenciado, criou as condições para a reprodução do recurso extraído e os meios para transportá-lo. A hidrologia e a topografia do rio modelaram diretamente as atividades humanas dirigidas a uma extração lucrativa. No caso da borracha, limitaram diretamente a velocidade e a proliferação de inovações tecnológicas das nações centrais, que incorporaram a borracha a uma crescente variedade de máquinas, cada vez mais produtivas e lucrativas. Os atributos espaciais e materiais da borracha e do sistema fluvial que condicionaram a produção natural e o acesso comercial a ela afetaram as oportunidades econômicas e a organização política e social das empresas e estados nas nações industrializadas, tanto quanto estas foram afetadas pelos comerciantes locais, pelos seringueiros, pelos proprietários de barcos e pelos políticos. Os modos como isso tudo afetou os diferentes grupos sociais, bem como o comportamento e a resposta de cada grupo, variaram bastante, de acordo com as diferentes posições em relação às características espaciais e materiais e aos processos 
técnicos e econômicos surgidos devido a essas características. As conseqüências dessas ações - seus custos e benefícios - também foram distribuídas de maneira desigual. Nesse sentido, os processos dinâmicos e seqüencialmente cumulativos das inovações tecnológicas e da organização social na extração, no transporte e no processamento da matéria resultam de dinâmicas interativas entre as dimensões locais e globais da natureza e da sociedade.

Essas dinâmicas recíprocas falsificam noções de construção social da natureza e do espaço. Os seres humanos não transformam ou constroem socialmente o espaço. No máximo, aceleram e intensificam seu próprio trânsito e o transporte de matéria por meio dele. 0 tempo não anula o espaço nesse modelo. $\mathrm{O}$ espaço, como condição de produção, proporciona oportunidades, ao passo que o espaço, como obstáculo ao transporte e a seu custo, constitui desafios que produzem inovações na organização social e na tecnologia.

As tentativas feitas para modelar essas dinâmicas surgiram a partir da Amazônia, onde são eminentemente salientes e, portanto, visíveis. Nas próximas seções, tentaremos mostrar como expandir esse modelo para explicar de que forma o espaço e a matéria - como contradição entre o custo da distância e as economias de escala - direcionaram a progressiva globalização do capitalismo. Demonstraremos, ainda, como a tensão entre as economias de escala e o custo do espaço impõe desafios técnicos e organizacionais, produzindo transformações sociais, políticas, econômicas e inovações tecnológicas, expandindo o espaço produtivo e comercial, bem como provocando a transformação da matéria, em cada um dos ciclos de acumulação (ARRIGHI, 1994).

A longo prazo, a acumulação seqüencial dessas transformações constitui os mecanismos subjacentes à globalização. Manteremos a atenção nas conseqüências globais dos processos locais na Amazônia para demonstrar que, mesmo que os resultados desses processos tornem-se globais, suas origens estão em características espaciais e materiais localmente observáveis e especificáveis. Tais características representam os desafios e as oportunidades que geram as economias de escala, tanto no transporte como na tecnologia, que levaram ao secular processo de globalização.

Nesse modelo, o mecanismo explicativo do centro relaciona a sucessão de configurações espaciais e materiais nas economias extrativas da Amazônia com as necessidades temporais e materiais das inovações tecnológicas. A freqüência, bem como a seqüência cumulativa da escala, produtividade e lucro dessas inovações refletem a intensificação material e a ampliação espacial da economia capitalista mundial. 
A seqüência de novas tecnologias justapõe-se e interage com as descobertas de recursos materiais, em determinados espaços. Freqüentemente, essas descobertas motivam ou aceleram a incorporação de periferias anteriormente externas ao sistema mundial. Atores locais - algumas vezes os índios ou as populações residentes, porém freqüentemente imigrantes respondendo às oportunidades econômicas proporcionadas por recursos recentemente descobertos - lideram a reorganização política, social e econômica em seus esforços para obter lucros com as novas demandas. Os lucros dependem da adaptação e da exploração das características espaciais e materiais dos recursos de forma que satisfaça as necessidades técnicas do processo de produção e as necessidades financeiras dos Estados e empresas que controlam essas técnicas.

A elite local responde às pressões e às oportunidades que a demanda expansiva e tecnológica do sistema mundial cria sobre as matérias- primas, modificando a ecologia que está sendo explorada, geralmente reduzindo sua capacidade de manutenção em relação à crescente demanda. Quando a relação entre a demanda global e o fornecimento local torna-se desproporcional, as empresas e estados das nações industriais escolhem e combinam diferentes estratégias. Essas estratégias incluem (1) pesquisas para encontrar novas fontes, geralmente maiores e com características físicas e espaciais mais compatíveis com novas demandas industriais, (2) inovações tecnológicas que barateiam o acesso a essas fontes novas e maiores e (3) invenção, melhoramento e barateamento de substitutos sintéticos. Cada uma dessas alternativas intensifica a dimensão material e amplia a dimensão espacial da economia mundial, enquanto desvaloriza o capital que a economia local alocou para adaptar-se às necessidades do sistema mundial em relação aos seus recursos.

Utilizamos narrativas empíricas do boom e da queda de cada um dos episódios extrativos para modelar as conseqüências espaciais e materiais do esgotamento e das deseconomias de escala na maioria dos sistemas extrativos. A partir dessas narrativas, deduzimos que os Estados e as empresas do centro mobilizaram a ciência, o comércio e as forças imperialistas e coloniais para resolver problemas de aumento de custo, escassez ou fornecimento inconsistente. Três soluções eram possíveis: (1) encontrar outra(s) fonte(s) da matéria- prima em questão, em outros locais, e para organizar ou catalisar os sistemas de transporte que assegurariam um fornecimento barato e estável desses materiais através do espaço, incorporando-se assim ao sistema mundial; (2) encontrar substitutos naturais, técnicos ou sintéticos para a matéria- prima em 
questão, como aconteceu com as tecnologias que substituíram o uso de óleos fornecidos pelo peixe-boi e pela tartaruga, entre outros, e os muitos usos da borracha, por petróleo; (3) domesticar e converter em plantações cultivadas os recursos naturais ou silvestres de matéria-prima, importando e organizando uma população suficientemente controlável para prover uma força de mão- de- obra barata e estável, como aconteceu com o cacau e a borracha.

As três soluções manipulam processos materiais, tanto naturais, como sociais, e realocam fontes de acordo com atributos sociais (por exemplo, demográficos, políticos e geopolíticos) e naturais (por exemplo, climatológicos, pedológicos e geológicos), conforme eles se relacionam às necessidades materiais da reprodução e extração da matéria-prima e aos determinantes espaciais, topográficos e hidrológicos do custo de acesso e de transporte. Essas três soluções proporcionaram o mecanismo para explicar a secular ampliação espacial e intensificação material da produção e do comércio do sistema mundial.

Utilizamos esse modelo espacial e material para organizar a análise das conseqüências locais, ambientais e sociais de cada economia extrativa e das demandas mutáveis por matérias-primas no sistema mundial, porém, mais adiante, abstraímos esses processos de um modelo termodinâmico de fluxos desequilibrados de energia, para explicar o sistemático subdesenvolvimento e instabilidade de economias extrativas.

Todos esses desafios de interpretação e a leitura dirigida das referências que havíamos ignorado, anteriormente, e que a bibliografia de Katzmann (1987) nos revelou, levaram- nos a procurar as razões pelas quais algumas periferias extrativas, mais notadamente nos Estados Unidos, mas também na Suécia, na Dinamarca, em partes da Alemanha, no Canadá e na Austrália, haviam, subseqüentemente, se industrializado o suficiente para atingir pelo menos uma participação parcial no ramo. Convencemo-nos, pouco a pouco, que os fluxos desequilibrados de energia eram muito abstratos e muito agregados para permitir a análise da produção específica - binária e multilateral - e das relações de troca que estruturaram e reorganizaram periodicamente a economia mundial. Os atributos físico- químicos das matérias- primas e sua localização no espaço, conforme determinado pela topografia, pela hidrologia, pela geologia, pelo clima e pela biologia, proporcionaram bases muito mais diretas para explicar as estratégias sociais e geopolíticas para a extração, o transporte, a transformação, a troca e o consumo da secular e crescente diversidade e do volume de bens.

A implementação dessas estratégias interagiu, necessariamente, com a economia e a geopolítica do espaço. Essa interseção significou 
que mecanismos espaciais e materiais não somente auxiliaram a explicar estratégias econômicas específicas, mas também demonstraram que essas estratégias modelaram a estrutura, o agenciamento e a organização sociais, dos níveis locais para os globais.

As compilações de Wittfogel (1985) sobre a análise de Marx dos sistemas naturais na produção de valores de uso, nossas próprias leituras da teoria de arrendamento de Marx (BUNKER, 1986, 1992) e a discussão de Carolyn Merchant (1983) sobre as visões de Francis Bacon e Agrícola acerca do imperativo de que todos os usos humanos de sistemas naturais seriam bem-sucedidos somente se sua tecnologia respondesse aos atributos químicos e materiais desses sistemas apontavam para os modos pelos quais os atributos físico-químicos da matéria entravam em todos os melhoramentos tecnológicos humanos. A própria diversidade da matéria dispersa pelo espaço proporciona os meios materiais e espaciais para a secular intensificação, proliferação, tecnificação e expansão, tanto do tipo como do volume da produção material, que controlam a dinâmica de crescimento e transformação do sistema. Tais considerações convenceram-nos de que a categorização tripartite do sistema mundial, de acordo com Wallerstein e sua tendência para usar a lógica categórica em vez de mecanismos baseados em matéria e espaço para explicar a dinâmica do crescimento e mudança impediam uma especificidade adequada das economias particulares ou locais.

Harvey (1983) combina seus próprios conceitos sobre o ambiente construído com a síntese da teoria de lugar central, de van Thunen, em sua avaliação da teoria de arrendamento de Marx. Em seu trabalho, ele explica os insights de Marx sobre o papel dependente do capital em relação ao Estado redistribui os enormes custos empatados nas tecnologias e infra- estrutura de transporte para incluir os vários agentes econômicos e sociais que delas se beneficiam. Marx foi muito claro ao afirmar que esses custos haviam aumentado enormemente à medida que o carvão, o ferro e o vapor tornaram possíveis novos meios de transporte e posteriormente proporcionaram valores de uso que podiam concretizar-se somente se as novas tecnologias de transporte pudessem movimentá- los de forma barata e em grandes volumes a partir de sua localização dispersa nos cada vez mais aglomerados centros industriais urbanos, criados pelo binômio máquina- fábrica. Entretanto, a atenção limitada dada por Harvey (1983) à dialética interna do capital privou- o de uma apreciação mais ampla da extensão da teoria do arrendamento de Marx, a qual especificava as implicações sociais e políticas de sua afirmação abstrata de que natureza e trabalho eram irrevogavelmente interdependentes na produção dos bens. 
As contribuições de Harvey (1983) sobre arrendamento, transporte e ambiente construído complementaram as explicações, conceitualmente diferentes, porém analiticamente complementares, de Innis $(1933,1956)$ sobre os custos, as dinâmicas e as conseqüências político- organizacionais que os sistemas de transportes desenvolveram para satisfazer as demandas por matérias- primas extraídas na periferia. A leitura conjunta de Harvey (1983) e Innis (1933) ajudou-nos a estender e a refinar as noções de sistemas de transporte como instrumentos intensivos em capital, criadores de débito e formados pelo Estado para articular fontes específicas e dispersas de matérias- primas com os centros concentrados de produção industrial, de acumulação de capital e de poder político. A análise espacial e material do financiamento, da construção e da utilização de tecnologias e de infra- estrutura específicos de sistemas de transporte, em períodos e espaços definidos, revela interesses e atividades específicos de diferentes grupos, tanto no centro, como na periferia. Tal análise pode explicar como a tecnologia e a infra- estrutura de transporte baratearam e aceleraram, progressivamente, o consumo de recursos naturais em cada ciclo da intensificação material e ampliação espacial do sistema mundial.

A análise espacial e material de (1) economias extrativas específicas e formações políticas em zonas periféricas, de (2) tecnologias, composição do capital, organização do trabalho, formação e reforma do Estado nas economias do centro e de (3) sistemas de transporte e comunicação que facilitam e barateiam o fluxo de material e a informação entre si revela o quanto esses processos conduziram, progressivamente, à globalização. Esses atributos e a secular evolução dos sistemas tecnológicos e políticos por eles gerada moldam as estratégias, os custos, a extensão espacial e os lucros das iniciativas do centro para explorar as múltiplas e diversas periferias em busca de seus vários recursos naturais. A continuidade transtemporal das interações entre os sistemas sociais, espaciais e materiais explica os processos seqüencialmente cumulativos que expandiram e intensificaram as relações produtivas e comerciais entre cada ciclo sistêmico de acumulação. Essa continuidade desacredita qualquer afirmativa de que a globalização é um fenômeno novo ou recente (SKLAIR, 2000). Na realidade, ela é o mais recente ou o último estágio dos processos espaciais e materiais, que evoluíram e acumularam seqüencialmente, por meio de diversas atividades específicas e interações de determinados grupos e organizações localizados (BUNKER, 1996; BUNKER; CICCANTELL, 1994, 1995, 2000, 2001). Paradoxalmente, isso é chamado de globalização apenas quando os processos atingem seus limites globais. 
A seqüência dos ciclos extrativos amazônicos aconteceu paralelamente à trajetória - e refletiu as tecnologias de produção e transporte - de cada ciclo sistêmico de acumulação ocorrido durante os quatro séculos da incorporação do Brasil ao sistema mundial. Os primeiros assentamentos e as guerras escravocratas foram uma resposta às lutas entre holandeses e portugueses pelo domínio do comércio na manufatura do açúcar e do ferro (SWEET, 1974; BUNKER, 1992). A exploração destrutiva das tartarugas respondia à luxuosa demanda por óleos combustiveis e por carne para as longas viagens oceânicas, em navios dependentes dos ventos, antes que as tecnologias industriais convertessem o petróleo em luz, refrigeração e força motora. A ascensão e a queda da economia da borracha coincidiram com o ápice do domínio industrial e comercial da Grã-Bretanha e com o surgimento do desafio americano na indústria pesada e até contribuíram para isso. Com o colapso do mercado da borracha e o uso crescente, pelas tecnologias dominantes, de minerais em vez de matérias como insumos primários, os vínculos que ligavam a Amazônia ao mercado mundial, entre 1920 e 1950, tornaram-se muito fracos. Até que a geopolítica da guerra fria e o papel crucial do aço na reconstrução da economia européia pós- guerra suscitaram o interesse norte- americano por fontes de manganês fora da União Soviética. Grupos brasileiros, política e economicamente poderosos, responderam aos sedutores apelos da Bethlehem Steel, formando uma grande empresa - que contou com garantias substanciais do governo brasileiro aos empréstimos do U.S. Ex-Im Bank - para exportar manganês do Amapá, um território isolado e de população esparsa, na margem norte do delta do Amazonas.

O manganês era um componente essencial para a confecção do aço, tanto pelo método Bessemer, como pelo de forno aberto. Ele era utilizado em proporções relativamente pequenas $-6,35 \mathrm{~kg}$ por tonelada de aço -, e o preço era suficiente para tornar comercialmente viável o seu transporte desde as localidades mais remotas do globo. Os depósitos da Serra do Navio eram altamente concentrados em uma área a $32 \mathrm{~km}$ de distância de um porto de águas profundas. A construção e a posterior operação da mina, da ferrovia e do porto geraram uma considerável prosperidade dentro de seus enclaves costeiros e lucros enormes ao capital concentrado que os controlava, porém tais efeitos eram espacial e materialmente mais limitados do que os do boom da borracha.

As trajetórias paralelas (1) dos ciclos cumulativos seqüenciais, tecnologicamente conduzidos, responsáveis pela intensificação material e ampliação espacial na economia mundial, e (2) das economias amazônicas extrativas e dependentes de demanda cristalizaram-se em 
1985, quando, após 20 anos de complexas negociações políticas e econômicas e da luta após sua descoberta inicial, Carajás, a maior mina de ferro do mundo, entrou em operação. A Companhia Vale do Rio Doce (CVRD), uma empresa brasileira de economia mista, que já exportava mais minério de ferro do que qualquer outra no mundo, adquiriu, construiu e operou a mina.

A construção absorveu o maior empréstimo internacional feito a um projeto de mineração em toda a história. Grande parte desse capital foi investido na maior ferrovia e no maior porto em termos de capacidade, dedicados a uma única mina. Os critérios determinantes do tamanho da mina, do porto e da ferrovia parecem ter sido os que eram necessários para competir nos mercados japonês e europeu. As economias de escala tinham de ser enormes para vencer as deseconomias do espaço, ao construir e operar uma mina localizada a $900 \mathrm{~km}$ do porto, passando por uma floresta densa e cruzando vários rios até chegar a um porto de águas profundas e produzir uma mercadoria tão volumosa e de baixo valor como o minério de ferro. Mesmo após a longa e difícil trajetória através da floresta, o porto ainda era mais longe do Japão do que o transporte comercial de carvão e ferro jamais haviam sido até então. 0 projeto, o financiamento, a construção e a operação da mina de Carajás representaram o último passo na globalização dos mercados do ferro e do carvão, graças a avanços tecnológicos na escala de mineração, transporte e processamento. Juntamente com o petróleo, esses dois materiais estão entre os de maior volume de consumo na produção industrial. Assim sendo, a competição industrial requer que tais materiais sejam relativamente baratos. Mesmo antes que o carvão e o ferro se tornassem materiais globalmente extraídos e comercializados, o transporte constituía, normalmente, a metade de seu custo. As inovações tecnológicas e as economias de escala na mineração, no transporte e na produção, que tornaram o minério de ferro de Carajás competitivo no Japão, foram, também o maior ingrediente da globalização.

Muito mais do que as conspirações internacionais ou as empresas e os Estados que asseguraram um fornecimento barato e estável de borracha, essa globalização dos mercados de ferro resultou de complexos processos de colaboração e competição entre Estados e empresas do centro, na medida em que catalisaram ações e iniciativas locais, interagiram com elas, para adaptar-se às características espaciais e materiais da nova periferia extrativa e explorá-las. As contradições entre os princípios do Interservices Intelligence (ISI) e as ideologias das nações periféricas, bem como as estratégias do Foreign Direct Investment (FDI) aplicadas às empresas multinacionais baseadas nos Estados Unidos, 
levaram a um amplo nacionalismo e à nacionalização de muitas minas e usinas beneficiadoras, durante a década de 60. Tais tendências representaram um obstáculo às maiores companhias mineradoras, que passaram a reter investimentos destinados à exploração ou à implantação de novos projetos. $\mathrm{O}$ Banco Mundial, em resposta à preocupação das nações centrais com relação a uma possível escassez de matéria-prima, mobilizou seus recursos técnicos, financeiros e diplomáticos para coordenar e suplementar empréstimos dos EUA, do Japão, da Alemanha, da União Européia e da Coréia para operacionalizar a mina de Carajás ${ }^{7}$. A maior parte desse empréstimo seria para pagar os enormes custos de infra- estrutura de transporte: $890 \mathrm{~km}$ de estrada de ferro, através da selva, e um grande porto capaz de acomodar a carga e a descarga de navios de 400.000 toneladas, no litoral.

A escala sem precedentes desse empréstimo foi proporcional à escala sem precedentes da mina e da infra- estrutura de processamento e transporte necessária à exportação do minério. A escala dessa infraestrutura foi calculada com base (1) nos atributos espaciais e materiais do depósito de minério de ferro, (2) nos atributos materiais e econômicos do próprio ferro, (3) nas características espaciais e materiais e econômicas da demanda potencial e do preço eventual do ferro e (4) nas economias de escala em transporte, que haviam tornado possível, graças ao mais recente estágio da expansão material e ampliação espacial, um mercado de carvão e ferro globalizado, baseado no transporte oceânico, em detrimento de um mercado regional, baseado no transporte terrestre (BUNKER; CICCANTELL, 2001).

Dentro da própria Amazônia, a proposta para a construção dessa infra- estrutura havia gerado uma enorme polêmica. $O$ rio Tocantins corria $150 \mathrm{~km}$ a leste dos depósitos de Carajás, através de matas de árvores de castanha- do- pará (Bertholletia excelsa), cuja produção era enviada rio abaixo para exportação a partir do porto de Belém, a capital do Estado do Pará. Os planos originais para a exportação do ferro por meio de uma parceria da U.S. Steel com a CVRD especificavam uma estrada de ferro da mina até o rio, transporte em balsas até Belém e carregamento em navios de longo curso, a partir de Belém. A US Steel opôs- se fortemente à preferência da CVRD pelo projeto muito mais caro que o Banco Mundial eventualmente havia coordenado e para o qual havia providenciado o

${ }^{7}$ A oportuna intervenção e participação do Banco Mundial nas negociações de empréstimos, em 1982, e sua intenção em relaxar seus procedimentos para atrelar o desembolso do empréstimo à conclusão dos estágios sequenciais específicos, sugerem que os esforços daquela entidade, neste caso, podem ter visado um objetivo adicional, que seria o de dificultar uma eventual moratória brasileira. 
financiamento. Em vez de sair pelo porto fluvial de Belém, o ferro seria exportado a partir de um porto litorâneo, no Maranhão, impedindo, assim, que o Estado do Pará arrecadasse, tanto os impostos diretos, como a receita indireta que a exportação a partir de Belém proporcionaria.

Entrevistas e pesquisa em arquivos no Rio de Janeiro, Tóquio e Washington D.C. sobre as origens dessa controvérsia sugeriram fortemente que a CVRD e a União haviam sido induzidas pelos japoneses e, em menor escala, pelos europeus a apoiar a alternativa ferroviária e não a fluvial, para a exportação. 0 porto de Belém poderia, no máximo, acomodar navios de 40 a 60 mil toneladas; o Maranhão podia acomodar, potencialmente, navios de mais de 400.000 toneladas. As exportações para a U.S. Steel, nos Estados Unidos, não percorreriam distâncias suficientemente longas para a economia de escala cobrir, na viagem, os custos adicionais fixos e as tarifas dos portos maiores ${ }^{8}$. Os portos europeus e japoneses, entretanto, eram suficientemente distantes. Em 1977, a CVRD comprou a parte da U.S. Steel por 50 milhões de dólares.

Com o auxílio do Banco Mundial, a CVRD utilizou e explorou as estratégias japonesas para dominar os mercados mundiais de aço e de transporte naval. A ação dos japoneses para dominar esse comércio havia eclipsado os setores, anteriormente dominantes da U.S. Steel, do aço e do transporte naval. As tecnologias de mineração, transporte e fundição, que haviam sido aceleradas pela topografia e pela geologia da região dos $\mathrm{G}$ randes Lagos, no século anterior, estavam agora sendo forçadas, pelas características espaciais e materiais, a competir com grandes navios, que podiam ser atendidos em portos de águas profundas, e com as grandes máquinas que podiam operar nos depósitos de Carajás.

As ações da CVRD nesses empreendimentos controversos revelaram, simultaneamente, (1) os processos espaciais e materiais e a estrutura de competição e colaboração no centro e seus efeitos em periferias material e espacialmente diferenciadas, (2) o conseqüente

\footnotetext{
${ }^{8}$ A regularidade espacial e material, nesse caso, decorre do fato de que a resistência da água contra o casco cresce proporcionalmente ao quadrado da profundidade do casco, enquanto o volume da carga cresce proporcionalmente ao cubo da profundidade do casco. A necessidade de combustivel por unidade de carga diminui com o aumento do tamanho do navio. Ao mesmo tempo, a necessidade de mão- de-obra aumenta proporcionalmente menos com o tamanho do navio. Essas duas constantes criam economias de escala consistentes em transporte naval. Porém, as economias de escala são contrabalançadas pelos custos de capital muito maiores envolvidos na infra- estrutura necessária para o acostamento e o carregamento e pelos custos ainda maiores de permanência no porto, como necessitam os grandes navios. Desse modo, as economias de escala acontecem somente quando a viagem em si é longa o bastante para contrabalançar os custos fixos extras de permanência no porto.
} 
papel das preferências e decisões de atores periféricos na reestruturação das relações da indústria periférica ${ }^{9}$ e (3) os impactos das crescentes economias de escala na extração, no transporte e no processamento das matérias- primas mais volumosamente consumidas na ampliação espacial episódica, porém de intensificação material cumulativa do sistema mundial (ARRIGHI, 1994), por meio de uma sucessão de diferentes ciclos dinâmicos de acumulação ${ }^{10}$.

Os processos espaciais e materiais e as relações que estruturaram as interações políticas, econômicas e financeiras em torno da construção social das instalações e da infra- estrutura de transporte coincidiram com a maciça expansão de escala nas diversas indústrias siderúrgicas das nações centrais. Isso incluiu: (1) o pico da expansão da produção de aço no Japão e de navios que dominam o comércio mundial em ambos os setores, (2) a entrada da Coréia no mercado mundial de aço, por meio da construção da maior instalação integrada de aço do mundo, (3) a mudança das instalações de processamento das companhias de aço européias para o litoral, onde estariam aptas a uma maior escala de fundição e transporte, necessária para competir com as drásticas reduções de custo e preços do aço, alcançadas pelos japoneses e pelos coreanos (JORNMARK, 1993), e pelos acordos de Plaza.

A expansão em escala e o remanejamento das indústrias de aço do Japão, da Europa e da Coréia para instalações no litoral resultaram na ampliação espacial e na intensificação material direta dos mercados de matérias-primas, enquanto os Acordos de Plaza aumentaram drasticamente as taxas de câmbio do yen japonês, os juros e custos de capital para todos os empréstimos feitos em yen, e baixaram o valor real das vendas internacionais de ferro, que eram transacionadas em dólar. O excesso de acumulação de capital líquido no Japão, que levou aos Acordos de Plaza (MURPHY, 1996), é fruto do sucesso japonês em reorganizar a distribuição espacial e material e a organização social dos mercados mundiais de metal de forma a facilitar a dominação japonesa

\footnotetext{
${ }^{9}$ Note- se que as preferências da CVRD afetaram não somente a posição do Brasil no sistema mundial, mas também a totalidade do mercado de ferro e aço. A adição de Carajás transformou o suprimento mundial em um mercado altamente inflexível, com implicações para todos os exportadores de ferro e para todos os beneficiadores industriais de aço.

${ }^{10} \mathrm{~A}$ participação japonesa nesse empréstimo multilateral foi, em si, um novo passo nas estratégias para reduzir a exposição de capital ao risco, por meio de joint ventures e contratos de longo prazo, que os japoneses haviam aperfeiçoado em suas negociações com a Austrália. Nesse caso, os japoneses foram bem- sucedidos ao estender o superávit gerado pelo excesso de capacidade nas minas mundiais a partes proporcionalmente menores, respondendo e associando-se à preocupação geral da indústria com a escassez de recursos (BOSSON; VARON, 1977; BUNKER; CICCANTELL, 2001).
} 
dos mercados mundiais de aço e da marinha mercante. 0 resultado acumulado dessa interdependência financeira, espacial e material das transformações foi a progressiva subordinação das nações periféricas, exportadoras de matéria- prima, às nações importadoras de matériaprima do centro (BUNKER; CICCANTELL, 2001).

Entretanto, essa subordinação envolvia as decisões e a participação ativa dos agentes locais na criação da infra- estrutura intensiva em capital e na adoção de novas tecnologias para as maciças economias de escala em mineração e transporte, que apoiavam os avanços feitos na escala de fundição e refinamento. A CVRD decidiu aproveitar as oportunidades que essas novas tecnologias abriram no mercado japonês e o acesso facilitado aos grandes créditos abertos pela coincidência da crise mundial da dívida externa e pelas preocupações dos países de centro com uma futura escassez de matéria- prima, contratando grandes empréstimos para (1) aumentar a capacidade extrativa da mina, (2) construir a linha férrea de alta capacidade até o litoral, (3) desenvolver um porto adequado para receber navios tão grandes que somente os portos japoneses e o porto de Rotterdam pudessem descarregá- los e (4) entrar em parcerias com as empresas japonesas de carregamento de minério acima de 450.000 toneladas.

\section{CONCLUSÃO: COMPARAÇÕES TRANSTEMPORAIS DO PROCESSO ESPACIAL E MATERIAL NA PASSAGEM DO LOCAL PARA O GLOBAL}

Cada um dos casos aqui resumidos mostra como os processos espaciomateriais locais na Amazônia se inter- relacionam e, parcialmente, constituem o sistema mundial, na medida em que provocam mudanças sistemáticas nos ciclos de acumulação e são por ela afetados. A atenção dada ao processo espacial e material é necessariamente ideográfica e complexa, porém as discretas características naturais - físicas, químicas, geológicas, hidrológicas, climatológicas, etc. - de cada local, bem como as discretas relações sociais - técnicas, econômicas, financeiras, etc. que se adaptam para explorá- las, manifestam, cada uma, os processos e mecanismos regulares a elas subjacentes. Essas regularidades e esses mecanismos possuem diferentes situações explicativas, e seu potencial, geralmente, varia de acordo com eles. As variações constituem um obstáculo à análise comparativa e histórica, porém as diferentes situações explicativas permitem uma análise do peso relativo dos diversos fatores naturais e sociais, conforme suas interações causam mudanças econômicas e ecológicas específicas no local e mudanças econômicas globais. 
A identificação das irregularidades e dos mecanismos pode, portanto, servir de apoio à análise comparativa dos materiais ao longo do tempo. A análise espacial e material constitui um meio de comparação de conjunturas, no decorrer de mudanças seqüenciais cumulativas na tecnologia, na produção e na densidade institucional, tanto nas relações Estado-empresas em formações sociais específicas, como no próprio sistema mundial ${ }^{11}$.

A incorporação de atributos espaciais e materiais específicos, que determinam como diversas matérias- primas e os locais de onde são extraídas participam do sistema mundial e o afetam, requer um trabalho empírico e analítico de magnitude e escopo além da capacidade individual. Ou seja, a exigência ideográfica de detalhes específicos em uma análise como essa exclui qualquer possibilidade de sucesso acadêmico em total isolamento. Nossa própria inspiração e nossa instrução nessa abordagem estão profundamente baseadas em trabalhos de campo de outras pessoas, que escreveram em determinadas épocas, sobre determinados eventos e em determinados locais da Amazônia.

Ao compararmos as estratégias de acesso e as tecnologias de transporte de Amsterdã, Grã-Bretanha, EUA e Japão, verificamos como as inovações tecnológicas, diretamente influenciadas pelas características materiais, levaram novas economias de escala às indústrias que consumiam o maior volume de matérias- primas, e como esses aumentos em escala aceleraram o esgotamento das fontes mais próximas e, conseqüentemente, deslocaram a busca de volumosas matérias- primas mais consumidas, através de espaços cada vez maiores. Economias de escala criaram, assim, sua própria contradição no aumento do custo da distância através do espaço; as reiteradas soluções para essa contradição podiam ser alcançadas somente por meio de maiores economias de escala em transporte, as quais, por sua vez, levavam a um aumento na escala de consumo de matérias- primas, reiterando, novamente, a contradição. A secular repetição desse ciclo, que se expande cada vez mais, sugere um modelo de soluções reiteradas de escala - com seus apanágios espaciais sempre presentes - como um mecanismo para o movimento constante do sistema mundial em direção à globalização.

As economias de escala em transporte e transformação de matérias-primas precederam cada uma das expansões do espaço

${ }^{11}$ A comparação de regularidades espaciais e materiais, baseada em interações locais específicas, permite comparações transtemporais que se sobrepõem às restrições de Millian, que exigem um controle de todas as variáveis, exceto uma. Tal comparação permite análises configuracionais (TILLY, 1995) e conjunturais (PAIGE, 1999) que podem superar as objeções de Paige à pesquisa social e científica em busca de regularidade e generalidade de explicações. 
comercial, identificadas por Arrighi (1994) como componentes de cada transição entre ciclos sistêmicos de acumulação. Arrighi (1994) explica essas expansões, primeiramente, como uma resposta combinada de Estados e empresas à superacumulação de capital na nação comercialmente dominante. Nesse sentido, Arrighi (1994) segue a explicação de David Harvey (1983) sobre o "fix espacial" ou a expansão geográfica do capital como solução para a superacumulação e a conseqüente desvalorização que emerge da "dialética interna do capital".

A análise dos processos que ligaram cada uma das economias extrativas da Amazônia às demandas variáveis da economia mundial leva- nos a discutir outra afirmativa que Harvey (1983) adota, com base em Marx: a tecnologia é uma mediadora entre a sociedade e a natureza. Em outras palavras, tentamos integrar a história espacial e material dos mercados e do transporte de matérias- primas mundiais à dinâmica financeira e política do capital mundial. Tecnologia e infra-estrutura podem moldar o espaço e a matéria somente com a intervenção direta da política e das finanças.

A história da Amazônia mostra que a tecnologia - tanto em transporte, como na produção - é cumulativamente expansiva em sua escala, em sua força e em seu custo. A análise comparativa das economias da borracha, do ferro e do alumínio na Amazônia sugere que as empresas e Estados centrais criam, promovem, financiam e implementam essas tecnologias como parte de suas estratégias para conseguir o domínio comercial. Para atingir as vantagens competitivas e a economia que o domínio comercial requer, as tecnologias devem estar em conformidade com as características materiais e a localização no espaço das matériasprimas, cujo transporte e transformação elas baratearam e expandiram.

Nesse sentido, as características espaciais e materiais das periferias extrativas impuseram limites às inovações obtidas pelas nações centrais. 0 determinante espacial e material da periferia é negado pela subordinação política e econômica dela às novas economias de escala. Cada episódio extrativo envolveu o transporte de maiores volumes de mercadorias - desde especiarias e óleo de tartaruga, às madeiras finas, borracha e minério de ferro-, de forma mais barata, através de distâncias maiores. Os investimentos crescentes em infra- estrutura de transporte foram cada vez mais repassados à economia local. Carajás, dependente do transporte global de um minério, cujo enorme consumo no mercado mundial baseia-se em seu valor muito baixo em relação ao volume, é, no mínimo, o exemplo mais dramático de como as tecnologias de transporte conseguiram solucionar a tensão entre a escala e o espaço, promovendo a globalização por meio do barateamento da tonelada/milha, 
às custas do fornecedor. Esse barateamento é essencial ao capital competitivo, na busca de matérias- primas em partes cada vez maiores do globo.

A fim de entender as expansões e intensificações espaciais e materiais e tecnológicas subjacentes à globalização, devemos especificar, ao mesmo tempo, a materialização geograficamente diferenciada do espaço, seguindo os atributos topográficos, hidrológicos, geológicos e climatológicos dos diversos locais, na medida em que eles determinam a qualidade e o caráter das matérias- primas, por meio das quais participam da economia mundial. $\mathrm{O}$ anverso essencial da materialização do espaço está na diferenciação espacial da matéria, conforme manifestado no local, em diferentes valores de uso.

Tanto a materialização do espaço, como a localização espacial da matéria impõem-se à atividade econômica de acordo com as tecnologias de extração, produção e transporte. As propriedades físicas e químicas específicas da borracha amazônica, por exemplo, tornaram-na mais flexível às manipulações técnicas das tecnologias industriais que dominavam o mercado mundial nos meados do século XIX. A utilidade e a abundância daquele tipo específico de borracha fizeram com que a maioria das inovações tecnológicas para melhorar e ampliar o seu uso fossem pesquisadas, desenhadas e implementadas em torno das propriedades químicas e físicas específicas da borracha amazônica. De forma similar, as tecnologias que lideraram a expansão e a progressiva mecanização da extração e da fundição do ferro, nos meados do século XIX, foram desenvolvidas em resposta às propriedades físicas e à localização topográfica dos enormes depósitos de minério de ferro em torno dos $\mathrm{G}$ randes Lagos, interagindo ao mesmo tempo com elas. Os lucros em potencial que motivaram os grandes investimentos em Carajás refletiram a compatibilidade física e química do depósito com as tecnologias mais lucrativas e o acesso dos depósitos às formas mais econômicas de transporte. Em outras palavras, as tecnologias de transporte e de transformação das matérias- primas mais volumosas expandiram-se e tornaram-se mais fortes em interação simultânea com os aumentos de escala na economia mundial e com os atributos espaciais e materiais das fontes locais específicas.

Nessa perspectiva, entretanto, a globalização como solução reiterada para as contradições espaciais e materiais das economias de escala no uso das matérias-primas mais volumosas, eventualmente, colidirá com os inexoráveis limites naturais do espaço e da matéria. Em âmbito local, a desigualdade entre as economias extrativas e produtivas (BUNKER, 1985; BUNKER; CICCANTELL, 2001) e o desequilíbrio do 
fluxo de matéria e energia da extração para a produção, que formam a base de nossa análise dos efeitos do desenvolvimento e do meio ambiente na ascensão e queda do ciclo da borracha na Amazônia (BUNKER, 1992), podem tornar-se ainda maiores, à medida que as economias de escala atingem esses limites naturais. Em âmbito global, a dialética interna do capital levou cada ciclo sistemático de acumulação primeiramente à exaustão local das matérias- primas tecnicamente mais acessiveis e, posteriormente, à superacumulação e desvalorização do capital na economia dominante.

Até então, cada episódio desses dilemas materiais e financeiros foi resolvido por um fix espacial, que incorporou novos tipos e depósitos de matéria-prima a novas tecnologias e infra- estrutura de transporte. Os investimentos em sistemas de transporte fizeram com que essas novas fontes de material fossem incorporadas ao mercado mundial, proporcionando, também, novos caminhos para a ampliação do comércio e dos investimentos nos mercados globais em expansão. À medida que materiais utilizados em grandes volumes e menor relação valor-volume são introduzidos no comércio global, cresce o potencial para futuras crises de exaustão de recursos e desvalorização de capital, enquanto diminui ou é eliminado o potencial para fixes espaciais, por meio da descoberta de novos e maiores depósitos em locais ainda mais distantes. A próxima grande crise de capital poderá ser o resultado de limitações espaciais e materiais, em lugar de respostas financeiras à superacumulação e à desvalorização. A questão será, então, se os Estados, empresas e setores - cuja estratégia de colaboração para atingir a dominação nacional do comércio mundial, por meio do investimento em novas economias de escala, resultou nessa crise - serão capazes de inventar novas formas de cooperação, que não exijam intensificação material ou ampliação espacial. 


\section{REFERENCIAS}

ALBION, Richard. Forests and Sea Power: The Timber Problem of the Royal Navy, 1652-1862. Cambridge: Harvard University Press, 1926.

ALDEN, Dauril. The Significance of Cacao Production in the Amazon Region during the Late Colonial Period: An Essay in Comparative Economic History. Proceedings of the American Philosophical Society, [S.1.], v. 120, n. 2, p. 103-135, apr. 1976.

ARRIGHI, Giovanni. The Long Twentieth Century. Money, Power, and the Origins of our Times. London: Verso, 1994.

BROCKWAY, Lucile. Science and Colonial Expansion: The Role of the British Botanical Gardens. New York Academic Press, 1979.

BOSSON, Rex; BENSON, Varon. The Mining Industry and the Developing Countries. Oxford: Oxford University Press, 1977.

BUNKER, Stephen G. Underdeveloping the Amazon: Extraction, Unequal Exchange, and the Failure of the Modern State. Urbana, IL: University of Illinois Press, 1985.

BUNKER, Stephen G. On Values in Modes and Models: Reply to Volk American Journal of Sociology, Chicago, v. 91, n. 6, p. 1437-1444, 1986.

BUNKER, Stephen G. Natural Resource Extraction and Power Diferentials in a Global Economy. In: ORTIZ, S.; LEES, S. (Ed.). Understanding Economic Process. Lanham, MD: University Press of America, 1992. p. 61-84.

BUNKER, Stephen G. The Political Economy of Raw Materials Extraction and Trade. In: SOCOLOW, R.; ANDREWS, C.; BERKHOUT, F.; THOMAS, V. (Ed.) Industrial Ecology and Global Change. Cambridge: Cambridge University Press, 1994a. p. 437- 450.

BUNKER, Stephen G. Flimsy Joint Ventures in Fragile Environments. In: BARHAM, B.; BUNKER, S.; O'HEARN, D. (Ed.). States, Firms, and Raw Materials: The World Economy and Ecology of Aluminum. Madison, WI: University of Wisconsin Press, 1994b. p. 261-296.

BUNKER, Stephen G. Raw Material and the Global Economy: Oversights and Distortions in Industrial Ecology. Society and Natural Resources, [S.1.], n. 9, p. 419- 429, 1996. 
BUNKER, Stephen G.; CICCANTELL, Paul. The Evolution of the World Aluminum Industry. In: BARHAM, B.; BUNKER, S.; O'HEARN, D. (Ed.). States, Firms, and Raw Materials: The World Economy and Ecology of Aluminum. Madison, WI: University of Wisconsin Press, 1994. p. 39-62.

BUNKER, Stephen G.; CICCANTELL, Paul. Restructuring Space, Time, and Competitive Advantage in the World-Economy. Japan and Raw Materials Transport after World War II. In: SMITH, D.; BOROCZ, J. (Ed.). A New World Order? Global Transformations in the Late Twentieth Century. Westport, Connecticut: Greenwood Press, 1995.

BUNKER, Stephen G.; CICCANTELL, Paul. Generative Sectors and the New Historical Materialism: Development and Underdevelopment in the World and National Economics. Paper presented at the ASA meetings, Washington, DC, 2000.

BUNKER, Stephen G.; CICCANTELL, Paul. International Inequality in the Age of Globalization: Japanese Economic Ascent and the Restructuring of the Capitalist World-Economy. Paper presented at the ISA meetings, Chicago, 2001.

BUNKER, Stephen G.; O'HEARN, D. Strategies of Economic Ascendants for Access to Raw Materials: A Comparison of the U.S. and Japan. In: PALAT, Ravi (Ed.). Pacific Asia and the Future of the World System. Westport, CT: Greenwood Press, 1992. p. 83-102.

CHASE-DUNN, Christopher, KAWANO, Yukio; BREWER, Benjamin. Trade Globalization since 1795: Waves of Integration in the World-System. American Sociological Review, n. 65, p. 77-95, 2000.

CICCANTELL, Paul; BUNKER, Stephen G. Space and Transport in the World System. Westport, CT: Greenwood Press, 1997.

CICCANTELL, Paul; BUNKER, Stephen G. Economic Ascent and the Global Environment: World-Systems Theory and the New Historical Materialism. In: GOLDFRANK, Walter et al. (Ed.). Ecology and World-Systems Theory. Westport, CT: Greenwood Press, 1999.

FITTKAU, Ernst Josef. Crocodiles and the Nutrient Metabolism of Amazonian Water. Amazoniana, [S.1.], v. 4, n. 1, p. 103-133, 1973.

HAYDU, J. Making Use of the Past. American Journal of Sociology, Chicago, v. 104, n. 2, p. 339-371, 1998. 
HARVEY, David. Limits to Capital. Oxford: Blackwell, 1983.

HEMMING, John. Red Gold: The Conquest of the Brazilian Indians. Cambridge: Harvard University Press, 1978.

HUGILL, Peter. World Trade Since 1431: Geography, Technology, and Capitalism. Baltimore, MD: Johns Hopkins University Press, 1994.

INNIS, Harold A. Problems of Staple Production in Canada. Toronto: Ryerson Press, 1933.

INNIS, Harold A. Essays in Canadian Economic History. Toronto: University of Toronto Press, 1956.

JORNMARK, Jan. Coal and Steel in Western Europe, 1945-1993: Innovative Change and Institutional Adaptation. Goteborg: University of Goteborg, 1993.

KATZMAN, Martin T. Review Article: Ecology, Natural Resources, and Economic Growth: Underdeveloping the Amazon. Economic Development and Cultural Change, [S.1.], v. 35, n. 2, p. 425-437, 1987.

LATHRAP, Donald W. Our Father the Cayman, Our Mother the Gourd: Spinden Revisited, or a Unitary Model for the Emergence of Agriculture in the New World. In: REED, C. A. (Ed.). Origins of Agriculture. Paris: Mouton Publishers, 1977. p. 713-731.

LEFEBVRE, H. The Production of Space. Oxford: Blackwell, 1991.

LEITNER, Jonathan. Upper Michigan's Copper Country and the Political Ecology of Copper, 1840's.1930's. Ph.D. dissertation, Sociology, University of Wisconsin-Madison, 1998.

MANDEL, Ernest. Late Capitalism. London: New Left Review Editions, 1975.

MARX, Karl. Capital: A Critique of Political Economy. New York International Publishers, 1967, v. 3.

MERCHANT, Carolyn. The Death of Nature: Women, Ecology, and the Scientific Revolution. San Francisco: Harper and Row, 1983.

MURPHY, R. Taggart. The Weight of the Yen. New York: Norton and Co., 1996. 
NIMUENDAJU, Curt. The Tapajo. Kroeber Anthropological Society Papers, [S.1.], n. 6, p. 1-12, 1954.

NORTH, Douglass C. Ocean Freight Rates and Economic Development, 17501913. Journal of Economic History, [S.1.], n. 18, p. 538-555, 1958.

O'ROURKE, Kevin H. O.; WILLIAMSON, J. Globalization and History: The Evolution of a Nineteenth-Century Atlantic Economy. Cambridge, MA: MT Press, 1999.

PAIGE, J. Conjuncture, Comparison, and Conditional Th eory in Macrosociological Inquiry. American Journal of Sociology, Chicago, v. 105, n. 3, p. 781-800, 1999.

PALMATARY, Helen Constance. The Archaeology of the Lower Tapajós Valley, Brazil. Philadelphia: Transactions of the American Philosophical Society, 1960.

ROBINSON, William I. Transnational Processes, Development Studies, and Changing Social Hierarchies in the World System: A Central American Case Study. Paper presented at ISA meetings, Chicago, 2001.

SANTOS, Roberto. 0 equilíbrio da firma 'aviadora' e a significação econômica institucional do "aviamento". Belém: IDESP, 1968 (Pará Desenvolvimento, 3).

SANTOS, Roberto. História econômica da Amazônia (1 800-1920). Sao Paulo: T. A. Queiroz, 1980.

SIOLI, Harold. Tropical River. The Amazon. In: WHITTON, B. A. (Ed.). River Ecology. Oxford: Blackwell Scientific Publications, 1975. p. 461- 488.

SKLAIR, Leslie. The Transnational Capitalist Class. Oxford: Blackwell Publishers, 2000.

SMITH, Neil. Uneven Development. Oxford: Blackwell, 1984.

SMITH, Nigel. Destructive Exploitation of the South American River Turtle. Association of Pacific Coast Geographers, n. 36, p. 85-101, 1974.

SMTH, Nigel. Caimans, Capybaras, Otters, Manatees, and Man in Amazonia. Biological Conservation, n. 19, p. 177-187, 1980-1981.

SOJA, E. Postmodern Geographies. New York Verso, 1989. 
SWEET, David. A Rich Realm of Nature Destroyed. Ph.D. dissertation (History) - University of Wisconsin-Madison, 1974.

TILLY, Charles. To Explain Political Processes. American Journal of Sociology, Chicago, n. 6, p. 1594-1610, 1995.

TOMICH, Dale. The World after the World System. Paper presented at the Social Science History Association, Pittsburgh, 2000.

WEINSTEIN, Barbara. The Amazon Rubber Boom, 1850-1920. Stanford, CA: Stanford University Press, 1983.

WITTFOGEL, Karl. Geopolitics, Geographical Materialism, and Marxism. Antipode, [S.1.], v. 17, n. 1, p. 21-72, 1985 [1929]. 